\title{
Cell Cycle Regulators during Human Atrial Development
}

\author{
Won Ho Kim, M.D., Chan Uhng Joo, M.D., Ja Hong Ku, M.D., \\ Chul Hee Ryu*, M.D., Keum Nim Koh**, M.D., \\ Gou Young Koh**, M.D., Jae Ki Ko, M.D. \\ Institute of Cardiovascular Research, Department of Obsterics and Gynecology*; \\ Cardiac Regeneration Group**, Chonbuk National University Medical School, \\ Cho nju, 560-180, Ko rea
}

Objectives : The molecular mechanis $m$ s that regulate cardiomyocyte cell cycle and terminal differentiation in humans remain largely unknown. To determine which cyclins, cyclin dependent kinases (CDKs) and cyclin kinase inhibitors (CKIs) are important for cardiomyocyte p rolife ration, we have examined prote in levels of cyclins, CDKs and CKIs during normal atrial development in humans.

Methods : Atrial tissues were obtained in the fetus from inevitable abortion and in the adult during surgery, Cyclin and CDK proteins were determined by Western blot analysis, CDK activities were determined by phosphorylation amount using specific substrate.

Results : Most cyclins and CDKs were high during the fetal period and the ir levels decreased at different rates during the adult period. While the prote in levels of cyclin D1, cyclin D3, CDK4, CDK6 and CDK2 we re still detectable in adult atria, the prote in levels of cyclin E, cyclin A, cyclin B, cdc2 and PCNA we re not detectable. Inte resting $b$, $p 27^{K I P I}$ prote in increased markedly in the adult period, while $p 21^{C I P I}$ protein in atria $w$ as detectable only in the fetal period. While the activities of CDK6, CDK2 and cdc2 decreased markedly, the activity of CDK4 did not change from the fetal period to the adult pe riod.

Co nc lus io n: These finding $s$ indicate that marked reduction of prote in levels and activities of cyclins and CDKs, and marked induction of $p 27^{K I P I}$ in atria, are associated $w$ ith the withdrawal of cardiac cell cycle in adult humans.

Ke y Wo rds : cyclin, CDK, CKI, atrium, cardiomyocytes, cell cycle

\section{INT RO DUCT IO N}

Cardiomyocytes in the fetal development exhibit abundant proliferative capability, whereas cardiomyocytes in the adult mammals exhibit litte, if any, capability to undergo cell division ${ }^{1-4)}$. Consequently, myocardial loss due to injury or disease during adulthood is irreversible, and the potential therapeutic value for myocardial regeneration is quite substantial. Knowledge of the

Address reprint requests to : Jae Ki Ko, M.D., Ph.D., Department of Intemal Medicine and Institute of Cardiovascular Research Chonbuk National University School of Medicine San 2-20, Keum-Am-Dong Chonju, 560-180, Republic of Korea mechanisms that control the cardiomyocyte cell cycle would allow us to design procedures to initiate repair or regeneration of the adult myocardium following injury. Unfortunately, we have yet to determine how the mammalian cardiomyocyte cell cycle is blocked after birth.

A number of cell-cycle regulated proteins have been identified and categorized as either cyclins, cyclin dependent kinases (CDKs) or cyclin dependent kinase inhibitors $(\mathrm{CKI})^{5-7)}$. The activity of CDKs control cell cycle progression, which activity is regulated positively and negatively by the association of CDKs with cyclins and CKIs, respectively ${ }^{8,9)}$. Cyclins and CDKs are classified as $\mathrm{G}_{1}$ (gap1), $\mathrm{S}$ (synthetic) or $\mathrm{G}_{2}$ (gap2)/M (mitotic) phase proteins, depending on the role and prote in abundance during the cell cycle ${ }^{5-7)}$. Presently, two families (INK and 
$\mathrm{CIP} / \mathrm{KIP}$ ) of $\mathrm{CKI}$ exist, and include $\mathrm{p} 15^{\mathrm{INK} 4 \mathrm{~B}} / \mathrm{p} 16^{\mathrm{INK} 4 \mathrm{~A}}$ $/ \mathrm{p} 18^{\mathrm{IN} \mathrm{K4}} / \mathrm{p} 19^{\mathrm{INK} 4 \mathrm{D}}$ and $\left.\mathrm{p} 21^{\mathrm{CIP} 1} / \mathrm{p} 27^{\mathrm{KIP} 1} / \mathrm{p} 57^{\mathrm{KIP} 2} 10,11\right)$. While the former family of CKIs bind to and inhibit only $\mathrm{G}_{1}$ phase cyclin-CDK complexes, the latter family of CKIs bind to and inhibit $\mathrm{G}_{1}$ and $\mathrm{S}$ phase cyclin-CDK complexes which leads to $\mathrm{G}_{1} / \mathrm{G}_{0}$ cell cycle $\operatorname{arrest}^{10,11)}$.

Recently, the importance of cell-cycle regulated proteins in cardiomyocytes has been recognized ${ }^{12-16)}$. Yoshizumi et $\mathrm{al}^{12)}$ reported that the disappearance of cyclin A, which is involved in DNA synthes is, correlates with permanent withdrawal of cardiomyocytes from the cell cycle in human and rat hearts. We have reported the reduction of various cyclins and CDKs protein expressions with differential and dramatic decrease of CDK activities in cardiomyocytes during the neonatal period, and we have hypothesized that the functionally active cdc2 in neonatal cardiomyocytes is involved in binucleation formation ${ }^{16)}$.

However, CDK activities and expression of CKIs in human hearts during development have not been examined. Therefore, we examined the expression and activities of cyclins, CDKs and CKIs in human atria during development in the human. We found that marked reduction of protein levels and activities of cyclins and CDKs, and marked induction of $\mathrm{p} 27^{\mathrm{KIP} 1}$, are associated with the withdrawal of cardiac cell cycle in adult humans.

\section{MATERIALS AND METHODS}

\section{Sa mpling}

Since the sampling of fresh ventricular tissues is very difficult from adult humans, we have chosen the sampling of atrial tis sue for this study. Atrial tissues of adult human were obtained from patients (48-55 years old) with mitral valvular disease during open heart surgery. Atrial tissues of fetus were obtained from gestation week 12 and 25-old fetus whose mother underwent surgery due to threatened abortion or premature labor. All samplings were conducted in our hospital from July 1997 to November 1997. Informed consent was obtained from each patient. Atrial tissues were immediately frozen in liquid nitrogen and stored $70^{\circ} \mathrm{C}$ until assayed, while the remaining half of specimens were fixed in $10 \%$ neutral formalin and routinely processed for pathologic study. Sprague-Dawley hosts and pregnant females were obtained from our breeding colony. Onset of pregnancy in female rats was determined by vaginal plug. Pregnant rats were killed at day 17 by decapitation and embryos were removed, decapitated and ventricles were harvested and stored in liquid nitrogen. Hearts were removed and ventricles were collected in the same manner from adult animals.

\section{Western blot}

Samples were homogenized in Nonidet P-40 buffer containing several protease inhibitors. Protein was quantitated, then separated by sodium dodecyl sulfatepolyacrylamide gel electrophores is (SDS-PAGE) system and electrotransferred to nitrocellulose membranes ${ }^{16)}$. The nitrocellulose membranes were blocked by incubation in blocking buffer, incubated with primary antibody, washed, incubated with horseradish peroxidase conjugated secondary antibody, and signals were visualized by the ECL detection method according to the manufacturer's protocol (Amersham Int. ple, Buckinghamshire, UK). Anticyclin D1 monoclonal antibody (72-13G), anti-cyclin D3 polyclonal antibody (C-16), anti CDK4 polyclonal antibody (C22), anti-CDK2 polyclonal antibody (M2), anti-cdc2 polyclonal antibody (pSTAIRE), anti-PCNA monoclonal

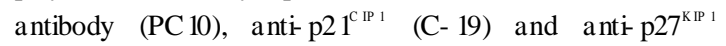
(N-20) were purchased from Santa Cruz Biotechnology Inc. (Santa Cruz, CA, USA). Anti- cyclin A and anti- cyclin B monoclonal antibodies were generously provided by Dr. Michael Brandeis (ICRF Clare Hall Lab. Cell Cycle Control, UK).

Immunoprecipitation and assay of each CDK activity

To measure CDK4 or CDK2 activity, the method of Jahn et al. ${ }^{17)}$ was slightly modified ${ }^{16)}$. Prote in lysates (500 g) were diluted with $1 \mathrm{ml}$ (final volume) of RIPA-buffer [1\% Triton $\mathrm{X}-100,1 \%$ sodium deoxycholate, $0.1 \%$ sodium dodecyl sulfate(SDS), $0.15 \mathrm{M} \mathrm{NaCl}$ and $0.01 \mathrm{M}$ Tris, $\mathrm{pH}$ 7.4] and precleaned with $50 \mu 1$ of prote in A-Sepharose CL-4B beads $(0.15 \mathrm{~g} / \mathrm{ml}$, Pharmacia Biotech, Uppsala, Sweden) for $1 \mathrm{~h}$ at $4^{\circ} \mathrm{C}$. The beads were then removed by centrifugation. Two $\mathrm{g}$ of CDK antibody was added to precleaned lysates in $1 \mathrm{ml}$ of RIPA-buffer, and the mixture was gently rocked for $2 \mathrm{~h}$ at $4^{\circ} \mathrm{C}$. Thirty $\mu 1$ of prote in A-Sepharose $\mathrm{CL}-4 \mathrm{~B}$ beads were added and the mixture was gently rocked for an additional $1 \mathrm{~h}$ at $4^{\circ} \mathrm{C}$. Immunocomplexes were collected by centrifugation $\left(3,000 \mathrm{~g}, 3 \mathrm{~min}, 4^{\circ} \mathrm{C}\right)$ and washed three times with 
ice-cold RIPA-buffer. Half of the immunocomplex bound beads was eluted in sample buffer, separated by SDS-PAGE, and Western blot analys is was performed as described previously. Purified CDK kinase activity in immunoprecipitates was measured using a modification of the methods previously described ${ }^{16)}$. Products of retinoblastoma protein ( $\mathrm{pRb}$, Santa Cruz) was used for determining the activities of CDK4 or CDK6 as the substrate. Histone H1 (Calbiochem, La Jolla, CA, USA) was used for determining the activities of CDK2 or cdc2 as the substrate. The remaining half of immunocomplexes bound beads was suspended in kinase buffer $(10 \mathrm{mM}$ $\mathrm{MgCl}, 5 \mathrm{mM} \mathrm{MnCl}, 1 \mathrm{mM}$ DTT, 50 mM HEPES- $\mathrm{NaOH}$, $\mathrm{pH}$ 7.3) and washed twice in kinase buffer. Reactions were carried out in kinase buffer (final volume, $50 \mu \mathrm{l}$ ) with $0.1 \mu \mathrm{g}$ of $\mathrm{pRb}$ or $2.5 \mu \mathrm{g}$ of histone $\mathrm{H} 1,0.1 \mathrm{mM}$ ATP and $5.0 \mu \mathrm{Ci}\left[Y-{ }^{32} \mathrm{P}\right] \mathrm{ATP}$ at $30^{\circ} \mathrm{C}$ for 20 minutes and stopped by adding $2 x$ SDS sample buffer. The optimum incubation time was determined by measuring several time points of $\mathrm{pRb}$ or histone $\mathrm{H} 1$ phosphorylation (data not shown). Final reactants were separated using SDS-PAGE, fixed with 5 to 10 volumes of glacial acetic acid:methanol:water (10:20:70), dried and autoradiographed. Signals were quantified using densitometry.

\section{RES ULTS}

Temporal changes of cyclin protein levels in human atria during the fetal and adult period (Fig. 1)

Anti-cyclin D1 antibody recognized two cyclin D1 bands that indicated phosphorylation status. The two cyclin D1 bands were readily detectable at gestation 12 weeks (G12W) and gestation 25 weeks (G25W). As the phosphorylated active from cyclin D1 (upper band) disappeared, the dephosphorylated inactive from cyclin D1 (lower band) was detectable at the adult period. The cyclin D3 levels decreased gradually from the early fetal period to the adult period. Cyclin E, A and B levels were high at G12W, decreased gradually at G25W and were not detectable at the adult period.

Temporal changes of CDK protein levels in rat ventricles and human atria during the fetal and adult period (Fig. 2)

The protein levels of CDKs and PCNA were high at

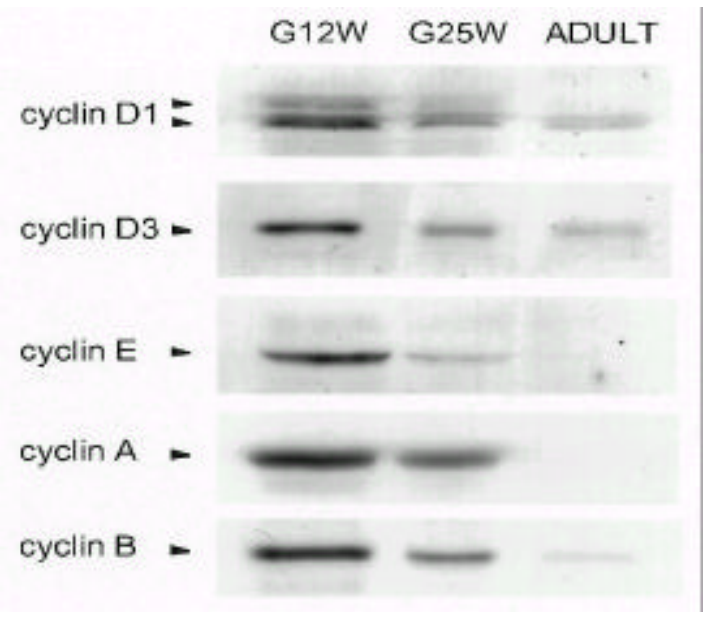

Fig. 1. Temporal changes of cyclin in atria during the fetal and adult periods. Parallel blots with total ysate protein $(50 \mu \mathrm{g})$ of atria are from gestational week $12(\mathrm{G} 12 \mathrm{~W})$ and $25(\mathrm{G} 25 \mathrm{~W})$ of a 55 year-old (ADULT). The antibodies used for each blot were described in the MATERIALS AND METHODS section. Results were similar to three separate experiments.

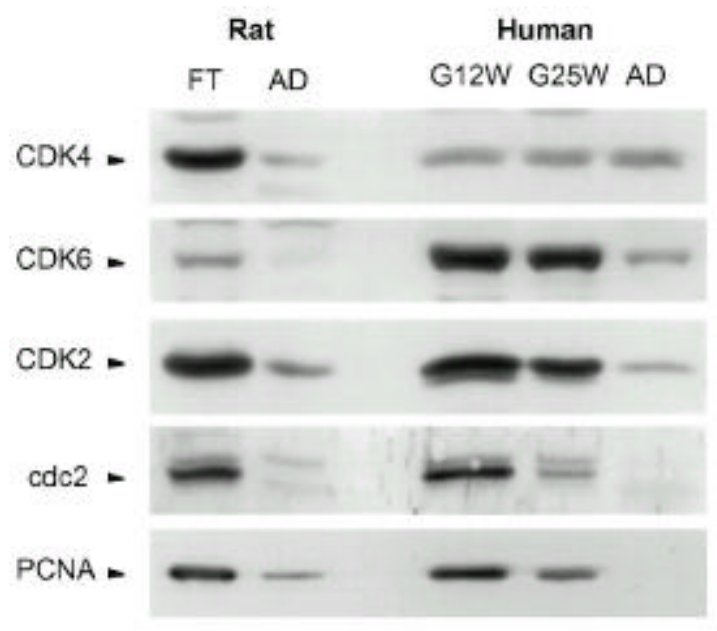

Fig. 2. Temporal changes of CDK protein levels in rat ventricles and human atria during the fetal and adult periods. Parallel blots with total ysate prote in $(50 \mu \mathrm{g})$ of ventricles are from gestational day $17(\mathrm{FT})$ and 150 day old (AD) ventricles in the rat and atria are from fetal gestational week $12(\mathrm{G} 12 \mathrm{~W})$ and $25(\mathrm{G} 25 \mathrm{~W})$ of a 55 year-old (AD) human. The antibodies used for each blot were described in the MATERIALS AND METHODS section. Results were similar to three separate experiments. 
the fetal period and their levels decreased markedly at the adult period in the rat. The CDK4 and CDK6 levels were high at G12W in human atria, and those did not change during the fetal period. Interestingly, while CDK4 levels did not change, CDK6 levels decreased from the fetal period to the adult period. CDK2, cdc2 and PCNA levels were high at G $12 \mathrm{~W}$, decreased gradually at G25W and decreased markedly at the adult period.

Changes of CDK activities in human atria during fetal and adult period (Fig. 3)

The specific antibodies for CDKs that were used for Western blot analysis were used to purify and measure the functional activities of CDKs. Each antibody bound its respective prote in in atrial lysates, and these immune complexes were immunoprecipitated as confirmed by Western blotting (data not shown). While CDK4 activity did not change from the fetal period to the adult period, activities of CDK6, CDK2 and cdc2 decreased markedly. The ratio (adult period to fetal period) of each CDK activity was 0.890 .11 (CDK4, $\mathrm{n}=3$, not $\mathrm{s}$ ignificant), 0.12 $0.02(\mathrm{CDK} 6, \mathrm{n}=3, \mathrm{p}<0.05), 0.180 .04(\mathrm{CDK} 2, \mathrm{n}=3, \mathrm{p}<0.05$, $\mathrm{CDK} 2)$ and $0.09 \quad 0.02(\mathrm{cdc} 2, \mathrm{n}=3, \mathrm{p}<0.05)$

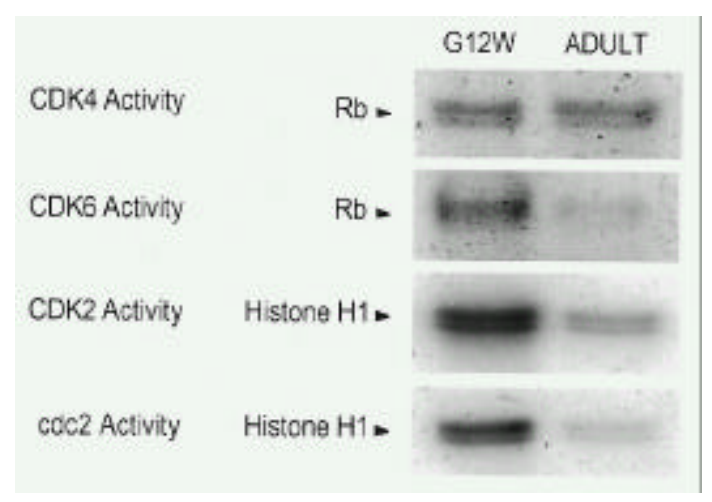

Fig. 3. Temporal changes of activities of CDKs in atria during the fetal and adult periods. Autoradiographic analyses were performed for activities of CDKs from immunoprecipitated complexes. pRb was used as substrate for CDK4 or CDK6 activities. Histone $\mathrm{H} 1$ was used as substrate for CDK2 and cdc2 activities. The detailed protocol is described in the MATERIALS AND METHODS section. The legends of ages are the same as shown in Fig. 1. Results were similar to three separate experiments.
Temporal changes of $\mathrm{p} 21^{\mathrm{CIP} 1}$ and $\mathrm{p} 27^{\mathrm{KIP} 1}$ prote in levels in human atria during fetal and adult period (Fig. 2)

The protein levels of $\mathrm{p} 21^{\mathrm{CIP} 1}$ and $\mathrm{p} 27^{\mathrm{KIP} 1}$ were readily detectable in atria during the fetal period. Interestingly, while $\mathrm{p} 21^{\mathrm{CIP} 1}$ in atria was not detectable at the adult

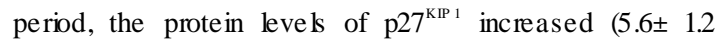
fold, $n=3, p, 0.05$ ) significantly in the adult period.

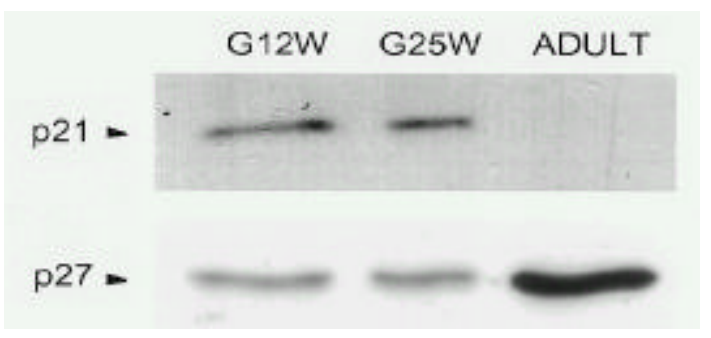

Fig. 4. Temporal changes of $\mathrm{p} 21^{\mathrm{CIP} 1}$ and $\mathrm{p} 27^{\mathrm{KP} 1}$ in atria during the fetal and adult periods. Parallel blots with total lysate protein $(50 \mu \mathrm{g})$ of atria are from gestational week $12(\mathrm{G} 12 \mathrm{~W})$ and $25(\mathrm{G} 25 \mathrm{~W})$ of a 55 year-old (ADULT). The antibodies used for each blot were described in the MATERIALS AND METHODS section. Results were similar to three separate experiments.

\section{IS C US S IO N}

The present study is designed to determine the changes of cyclins, CDKs and CKI proteins in human atria during the fetal and adult periods. These findings indicated that the protein levels of most cyclins and CDKs were high in atria during the fetal period, then they decreased at different rates. While the activities of CDK6, CDK2 and cdc2 decreased markedly, the activity of CDK4 was not changed. While $\mathrm{p} 21^{\mathrm{CP} 1}$ prote in in atria was detectable only in the fetal period, $\mathrm{p} 27^{\mathrm{KIP} 1}$ prote in increased markedly in the adul period. In this study, cardiomyocytes may have contributed greatly to the levels of cyclin, CDK and CKIs from whole atria, though contribution of non-myocytes could not be ruled out. These findings indicate that reduction of cyclin and CDK levels, and induction of $\mathrm{p} 27^{\mathrm{KIP} 1}$ level, are associated with the withdrawal of atrial cell cycle and block the ability of adult cardiomyocytes to re-enter the cell cycle after injury.

The mammalian cell cycle consists of $\mathrm{G}_{1}, \mathrm{~S}, \mathrm{G}_{2}$, and 
$M$ phases. D-type cyclins are synthesized in early G1 phase, and they bind to and activate CDK4 as cells leave the quiescent phase $\mathrm{e}^{5-7)}$. The cyclin $\mathrm{D} /$ cyclin $\mathrm{D}$ complex phosphorylates retinoblastoma prote in $(\mathrm{Rb})$ in the late $\mathrm{G} 1$ phase of cell cycle, canceling Rbs growth-suppressive function and, thereby, facilitating S-phase entry. DNA synthesis occurs in the $\mathrm{S}$ phase of cell cycle with activation of cyclin $E, A^{8,9)}$. Binding of cyclin $A$ or $E$ is necessary for activation $\mathrm{CDK} 2$. Cyclin $\mathrm{B}$ binds to cyclin $\mathrm{B}$ and controls entry into mitosis ${ }^{8,9)}$. Thus, the previous ${ }^{16)}$ and the present studies indicate that cyclins and CDKs are actively involved in cell cycle progression of cardiomyocytes during the fetal period. There is a rapid transition from $\mathrm{G}_{1} / \mathrm{M}$ phase of cell cycle to $\mathrm{G}_{0} / \mathrm{G}_{1}$ phase of cell cycle in cardiomyocytes during the late gestational and early neonatal periods in experimental animals ${ }^{18,}{ }^{19)}$.

Yoshizumi et al., ${ }^{12}$ and our previous data ${ }^{16)}$, suggested that disappearance of cyclin A was correlated with withdrawal of cardiomyocytes from the cell cycle in human and rat hearts. In addition, the present data indicate that disappearance of cyclin E or B also may be a candidate cyclin for withdrawal of cardiomyocytes from the cell cycle in human atrium. D-type cyclins are synthesized as long as growth factor stimulation is persistent ${ }^{5-7)}$. However, they are rapidly degraded when growth factors or mitogens are withdrawn, regardless of the position of the cell in the cell cycle. Growth factors act on adult hearts in an autocrine or paracrine manner ${ }^{2022)}$ and may induce relatively constant D-type cyclins. In this study, adult atria expressed cyclin D1 and D3 proteins. A similar pattern was also observed in rat hearts during development ${ }^{16)}$.

In order to function in the cell cycle, each cyclin must bind to a specific $\mathrm{CDK}^{8,9)}$. Most $\mathrm{CDK}$ protein levels and activities were high in atria during the fetal period and those were very low or undetectable levels during the adult periods. Hence, most CDKs could influence the cardiomyocyte cell cycle. PCNA, a DNA polymerase - associated protein, was used as a marker for cell proliferation ${ }^{23)}$. The temporal pattern of PCNA during cardiac development was similar to the pattern of CDKs and was consistent with another report ${ }^{24)}$. However, no significant changes occurred in levels and activities in CDK4 during development in human atrium. It is not clear why there is a species difference between rats and humans ${ }^{16)}$.

The present data indicate that the protein levels of $\mathrm{p} 27^{\mathrm{KIP} 1}$ increased significantly in the adult atria. The actual nuclear amount of $\mathrm{p} 27^{\mathrm{KIP} 1}$ in cardiomyocytes may be increased more if we account the decreased ratio of nuclear/cytoplasmic volume between the fetal and adult period $^{25-27)}$. Because the amount of $\mathrm{p} 27^{\mathrm{KIP} 1}$ protein paralleled temporally the inhibition of CDK activity in all instances investigated, the protein abundance is likely the primary mode of $\mathrm{p} 27^{\mathrm{KIP} 1} \operatorname{action}^{8,9)}$. Therefore, these present data suggest that the high levels of $\mathrm{p} 27^{\mathrm{KIP} 1}$ protein in atria at the adult period may be a principal inhibitor for cardiomyocyte cell cycle progression after injury. The transgenic animal model, with its selective gene disruption, provides an invaluable tool for understanding the in-vivo function of a selected gene. While all organs have detectable amounts of $\mathrm{p} 27^{\mathrm{KIP} 1}, \dot{\mathbf{t}}$ is most abundant in the thymus and spleen in mice ${ }^{28-30)}$ and rats [our laboratory unpublished observation]. Hearts have approximately $20-25 \%$ of $\mathrm{p} 27^{\mathrm{KI} 1}$ prote in compared to the spleen in rats [our laboratory unpublished observation]. Transgenic mice lacking p27KIP1 have grossly normal development but display several phenotypes linked to increased cell proliferation ${ }^{28-30)}$ such as increased body size and multiple organ hyperplasia. A positive correlation between the expression amount of $\mathrm{p} 27^{\mathrm{KIP} 1}$ prote in in an organ and the increase in weight of the organ following $\mathrm{p} 27^{\mathrm{KIP} 1}$ gene disruption was observed. Thus, while there is a 1.8-fold increase of weight in spleen and thymus, 1.2-1.3-fold increase of weight in brain and heart were observed in the $\mathrm{p} 27^{\mathrm{KIP} 1}$-lacking mice ${ }^{29}$. The increased organ weights result from more increased cell cycle. These results from mice lacking $\mathrm{p} 27^{\mathrm{KIP} 1}$ strongly support our data that mainly $\mathrm{p} 27^{\mathrm{KIP} 1}$ limits cell proliferation by inhibiting $G_{1}$ and $S$ phase cyclin-CDK complexes in cardiomyocytes during development and after injury.

\section{S UMMA RY}

We have shown that cyclins, CDKs and the CIP/KIP family of CKIs are highly detectable in human atriums during the fetal period and that, differential change occurred at the adult period. Marked reduction of protein levels and activities of cyclins and CDKs are responsible for withdrawal of atrial cardiomyocytes from the cell cycle. Notably, marked induction of $\mathrm{p} 27^{\mathrm{KP} 1}$ in adult atrium may be an important inhibitor for blocking the ability of adult cardiomyocytes to re-enter the cell cycle after injury.

\section{Acknowle dge ments .}

This work was supported by research funds of Chonbuk National University (1996-1997) and KSTEPI (1997- 1998). 


\section{REFERENCES}

1. Peterson RO and Baserga R: Nucleic acid and protein synthesis in cardiac muscle of growing and adult mice. Exp. Cell. Res. 1965;40,340-352.

2. Rumyantsev, PP: Interrelationship of the prolifeartion and differentiation processes during cardiac myogenesis and regeneration. Int. Rev. Cytol. 1977;5 1, 187-273.

3. Clubb FJ Jr and Bishop SP: Fomation of binucleated myocardial cells in the neonatal rat. Lab. Invest. 1984;50: 571-577.

4. Claycomb WC: Control of cardiac muscle division. Trend. Cardiovas. 1992;2:23 1-236.

5. Hunter T and Pines J: Cyclins and cancer. Cell 1991;66: $1071-1074$.

6. Hunter T and Pines J: Cyclins and cancer II: cyclin D and CDK inhibitors come to age. Cell 1994;79:573-582.

7. Sherr CJ: G1 phase progression; cycling on cue. Cell 1994;79:55 1-555.

8. Morgan DO: Priciples of CDK regulation. Nature 1995;374: $131-134$.

9. Lees E: Cyclin dependent kinase regulation. Curr. Opi. Cell Biol 1995;7:773-780.

10. Harper JW and Elledge SJ: $C D K$ inhibitors in development and cancer. Curr Opin. Genet. Dev. 1996;6:56-64.

11. Sherr CJ: Cancer cell cycles. Science 1996;274:16721677.

12. Yoshzumi M, Lee WS, Hsieh CM, Tsai JC, Li J, Perrella MA, Patters on C, Endege WO, Schlegel R and Lee ME: Disappearance of cyclin A correlates with permanent withdrawal of cardiomyocytes from the cell cycle in human and rat hearts. J. Clin. Invest. 1995;952275-2280.

13. McGill CJ and Brooks G: Cell cycle control mechanisms and their role in cardiac growth. Cardiovas. Res. 1995;30: 557-569.

14. Kang MJ, Kim JS, Chae SW, Koh KM, and Koh GY: Cyclins and cyclin dependent kinases during cardiac development. Mol. Cells 1997;7:360-366.

15. Sadoshima J, Aoki $\mathrm{H}$ and Zumo $\mathrm{S}$ : Angiotensin II and serum differentially regulate expression of cyclins, activity of cyclin-dependent kinases and phosphorylation of $p R b$ in neonatal cardiomyocytes. Circ. Res. 1997;80228-24 1.

16. Kang MJ and Koh GY: Differential and dramatic changes of cyclin dependent kinase activities in cardiomyocytes during the neonatal period. J. Mol. Cell. Cardiol. 1997;29: 1767- 1777.

17. Jahn L, Sadishima J and Zumo S: Cyclins and cyclindependent kinases are differentially regulated duning teminal differentiation of C2CD muscle cells. Exp. Cell Res. 1994;2 12 297-307.

18. Erokhina IL and Rumyantsev PP: Proliferation and biosynthetic activities of myocytes from the conductive system and working myocardium of the developing mouse heart. Light microscopic autoradiographic study. Acta.
Histochem. 1988;84:51-66.

19. Rumyantsev PP: In Growth and Hypeplasia of Cardiac Muscle Cells, p 70-199, Harwood Academic Publisher, 1991.

20. Casscells W, Bazoberry F, Speir E, Thompson N, Flanders K, Kondaiah P, Ferrans VJ, Epstein SE and Sporn M: Transforming growth factor- $\beta$ in nomal heart and myocardiac infarction. Ann. NY. Acad. Sci. 199 1;593: 148- 161

21. Engelmann GL, Boehm KD, Haskell JF, Khairallah PA and Ilan $\mathrm{J}$ : Insulin-like growth factors and neonatal cardiomyocyte development: Ventricular gene expression and membrane receptor variation in nomotensive and hypertensive rats. Mol. Cell. Endocrinol. 1989;63:1-14.

22. Engelmann GL, Dionne CA and Jaye MC: Acidic fibroblast growth factor and heart development. Circ. Res. 1993;72:7- 19 .

23. Marino TA, Haldar S, Williamson EC, Beaverson $K$, Walter RA, Marino DR, Beatty $\mathrm{C}$ and Lipson $\mathrm{K}$. Prolifearting cell nuclear antigen in developing and adult rat cardiac muscle cells. Circ. Res. 199 1;69:1353- 1360.

24. Bravo R, Frank R, Blundell PA and MacDonald- Bravo $\mathrm{H}$ : Cyclin PCNA is the auxillary protein of DNA polymerase-. Nature 1987;326:515-517.

25. Anversa P, Olivetti G and Loud AV: Mophometric study of early postnatal development in the left and right ventricular myocardium of the rat. I. Hypertrophy, hypeplasia, and binucleation of myocytes. Circ. Res. 1980;46.495-502.

26. Olivetti G, Anversa P, and Loud AV: Mophometric study of early postnatal development in the left and right ventricular myocardium of the rat. Circ. Res. 1980;46: $503-5 \mathrm{D}$.

27. Li F, Wang X, Capasso JM and Gerdes AM. Rapid transition of cardiac myocytes from hypeplasia to hypertrophy during postnatal development. J. Mol. Cell. Cardiol. 1996;28:1737- 1746.

28. Nakayama K, Ishida N, Shirane M, Inomata A, Inoue $\mathrm{T}$, Shishido N, Horii I, Loh DY, and Nakayama K: Mice

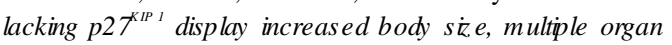
hypeplasia, retinal dysplasia and pituitary tumors. Cell 1996;85:707- 720.

29. Kiyokawa H, Kineman RD, Manova-Todorova KO, Soares VC, Hoffman ES, Ono M, Khanam D, Hayday AC, Frohman LA and Koff A: Enhanced growth of mice lacking the cyclin-dependent kinase inhibitor function of p2 ${ }^{K I P}{ }^{1}$. Cell 1996;85:72 1-732.

30. Fero ML, Rivkin M, Tasch M, Porter P, Carow CE, Firpo E, Polyak K, Tsau LH, Broudy V, Perlmutter RM, Kaushansky $\mathrm{K}$ and Roberts $\mathrm{JM}$ : A syndrome of multiorgan hypeplasia with features of gigantism, tumorigenesis and female sterility in $p 27^{K I P I}$-deficient mice. Cell 1996;85:733-744. 